\title{
BASAER Team: The First Arabic Robot Team for Building the Capacities of Visually Impaired Students to Build and Program Robots
}

\author{
https://doi.org/10.3991/ijet.v16i24.27465 \\ Mahmoud Hamash ${ }^{(凶)}$, Hasnah Mohamed \\ Universiti Teknologi Malaysia, Johor, Malaysia \\ mohammad20@graduate. utm. my
}

\begin{abstract}
The purpose of this study was to examine whether visually impaired students can build educational robots and program them if they receive adapted materials and instructions with guided instruction from a well-trained educators in the fields of inclusive STEM Classrooms. Discussion of the technologies and our experimental approach is presented in this paper and validated through the continued successful effort with visually impaired students for two years of the program and specialists in the field of visual impairment and STEAM, we also validated our approach by performing experimental classes for students with different visual impairments and ages. The results indicated that the approach used by BASAER team was successful in enabling the blind and visually impaired student to build and program educational robots and to participate effectively in national and international STEAM programs and competitions, with some limitations and Challenges encountered and explored during this research. The results from this study will be used to suggest a fully adapted system to support full inclusion for blind and visually impaired students in educational robots in STEAM context and to promote the adoption of this study and similar studies toward Inclusive STEM Classrooms.
\end{abstract}

Keywords - visually impaired, BASAER, robotics, STEAM, accessibility, programing

\section{Introduction}

Visually impaired and blind students need exposure to real-world situations and to be provided with such opportunities from an early age to remain competitive in the world of science, technology, engineering, art and mathematics (STEAM) [1]. Moreover, in the last few years, the humane aspect of society has seen changes that manifest themselves in the increasing attention given to the issues of social inclusion of people with disabilities [2] and a better understanding of special needs at different educational levels [3]. Thus, the education community needs to develop new and exciting learning models for teachers who work with blind or visually impaired students, bringing these students closer to real-world scenarios to expose them to careers in science and technology. It should be standard practice for all students to have hands-on science and 
technology experiences that are applicable to their individual needs regardless of their disabilities.

BASAER as described in more details in reference [4] is a program started in 2015 in the Blind Academy in Jordan, and at that time there were no efforts that are deployed to engage students with disabilities in the fields of computing and robotics, including the blind academy in Jordan and other blind schools and institutes in the Arabic world. BASAER team efforts differ from other related projects in its attempt to engage Visually Impaired students by focusing on accessible resources for robot building and programming plus educator training and awareness. This project aimed to provide engineering and computing content via robotics as a delivery mechanism while providing infrastructure to engage Visually Impaired students in STEAM classes. This approach required a series of steps to address a question related to whether visually impaired students can build and program educational robotics. The first step was Researching the literature for studies and analyses of similar projects, The second step was to search for educational Robotic technologies available on the market that would facilitate teaching Visually Impaired students or could be modified to facilitate such training, The third step was to provide the educators of this program with the specialized training they required, The fourth step was to create a modified hands-on curriculum for introducing robot building to visually impaired students that engages them in the engineering design necessary to accomplish the program objectives, In the fifth step, current educational programming software and interfaces were investigated and compared so that Visually Impaired students could access robotic programming activities, the sixth step entails the development, implementation, evaluation, and refinement of BASAER project in collaboration with the Blind Academy for the Visually Impaired and the Ministry of Education.

In this paper, the researcher discusses these steps for developing the capabilities of blind and visually impaired students to build and program educational robots, which has been validated with both Visual Impaired students and adults, and also with experts in the mentioned fields.

\subsection{Definitions}

Visually impaired. Vision Impairment is a condition in which an individual loses his or her ability to see clearly, thus affecting their development and life performance in ordinary daily activities. In order to determine which people qualify for special assistance because of their visual disabilities, individual governments have specific definitions of legal blindness. Visually impaired individuals can be divided into two groups as stated in [5]:

1. Blind: They are divided into two categories:

(a) Severely sight impaired: Defined as having a central visual acuity of less than $3 / 60$ with normal fields of vision, or gross visual field restriction and Unable to see at 3 meters, where the normally sighted person sees at 60 meters. 
(b) Sight impaired: Defined as having a visual acuity of less than $6 / 18$ but greater than $3 / 60$ and able to see at 3 meters, but not at 6 meters, where the normally sighted person sees at 60 meters.

2. Low vision: Defined as having a visual acuity of less than $6 / 18$ but greater than $3 / 60$ and Not eligible to drive and may have difficulty recognizing faces across a street, watching television, or choosing clothing.

BASAER team. BASAER is an Acronym that stands for the following words (Blind Academy Science and Educational Robot). And it is the name of the first Arabic educational robotics team for blind students which was created in 2015 in the Blind Academy School in Amman, Jordan by three teachers.

Educational Robotics (ER). The field of Educational Robotics is the field which aims to improve learning experiences of individuals by devising, implementing, improving, and validating pedagogical activities, tools, and technologies in which robots play a real role and pedagogical teaching methods are used to make each decision [6].

STEM is a multidisciplinary approach to education in which the traditional five domains of Science, Technology, Engineering, Arts, and Mathematics are incorporated into a single theme to promote critical thinking, learning, and enquiry [7]. And In STEAM classrooms, students are guided through inquiry, dialogue, and critical thinking [8], through STEAM, students take thoughtful risks, work through experiential learning, persevere in problem solving, embrace collaboration, and develop their skills at problem solving These are the innovators, educators, leaders, and learners of the $21^{\text {st }}$ century as stated in [9], which also state that this approach has five steps:

- Determining problems

- Designing methods of solving problems

- Producing instruments or projects for problem solving activities

- Testing, evaluating, and improving

- Presenting students' work

\section{$2 \quad$ Literature review}

Alzireqat [10] proposed that some adolescents with visual disabilities do not accept themselves as disabled people, which prevents them from participating in certain activities. Furthermore, this also causes them to be isolated from their peers. And As a result of this situation, blindness has a major effect on social growth for the blind.as previously indicated the impact of visual impairment on visually impaired students affected their growth in all growth areas, but that doesn't mean that they are unable to continue in their life and catch up with their education and development if circumstances are adapted to support them and provide them with the potential, tools and methods to be inspired to continue their learning as sighted peers.

Students with visual impairments have traditionally been unable to access science, Chemistry, physics, engineering, biology, and mathematics. As they make use of visual presentations of concept and information. This visual information has not been made 
available for widespread use in a format easily accessible to blind and Visually Impaired students. Thus, for visually impaired students, there should be accommodations for learning and for the environment. Blind students may need preferential seating since they mostly listen to their instructors. Lab equipment should be adapted to be accessible to visually impaired students in order to protect their self-esteem and independence. Based on a research paper by Sahin \& Yorek [11] A well-designed adaptation should provide for safety and proactively prevent any possibility of hazardous situations, research has shown that it is possible for Visual Impaired students to learn and study scientific subjects as well as sighted students, provided that they are provided with a modified learning environment and are taught by teachers who are skilled in teaching science and math to Visually Impaired students. And also for educators to support their pupils learn crucial knowledge and capabilities, they need to be aware of available technology and special technology programs as stated in [12].

In another study, centered on Computer Science Principles for Teachers of Blind and Visually Impaired Students, a course was developed for one major aim, which was to broaden participation and to make Computer Science Principles (CSP) more accessible to students with disabilities. The research procedure included two main stages: First, the entire Code.org CSP course was modified to become accessible with the help of accessibility experts and teachers. Secondly, through conducting a one-week professional development workshop in the summer of 2018, researchers prepared teachers of blind or visually impaired students to assist students with CSP, the results from this research indicate the efficacy of this approach [13]. The number of visually impaired students who enroll in computer science is relatively small despite advances in assistive technology. Significant factors in this underrepresentation include lack of precollege programs and isolation from computer science, preparation, and access to resources, and the highly visual nature of computing [14].

The same is true for the robotics field which integrates multiple aspects of computer science and engineering. Unfortunately, the opportunities offered for teachers of these students with disabilities are still inadequate. This is mostly due to the scarcity of accessible platforms for educational robots, and the lack of familiarity among teachers with alternative teaching methods, like nonvisual teaching methods [15]. Therefore, educators have an important role in ensuring these students participate in robotics to enhance learning and interest in STEM. Several adaptations to the robotics program can help to increase participation among children with disabilities. The adapted STEM programs addressed the educational/curriculum, cognitive/learning, physical, and social needs of the students. The research results indicate that the students enjoyed the adapted STEM programs in which they learned about computer programming and building robots as proposed by Lindsay \& Housel [16].

\section{$3 \quad$ Methodology}

An experimental project was launched under the name of BASAER team in order to advance the development of blind and visually impaired students' abilities to build and 
program robots, and in order to answer the question of whether Visually Impaired students can build and program educational robots, this experimental approach has five steps: 1. Determining problems 2. Designing methods of solving problems 3. Producing instruments or projects for problem solving activities 4. Testing, evaluating, and improving 5. Presenting students' work.

BASAER team was created with zero budgets to begin with and was fully initiated by team members and teachers, with the principal's support. The team was managed and trained by three teachers from the Blind academy school, teacher expertise were chosen carefully by the team manager as follows: 1-Team manager and trainer (Science teacher and expert in educational technologies, Male / sighted person). 2- Team trainer 02 (English teacher, with great experience in team work with blind students. And also excellent math skills, Male / totally Blind.). 3- (Team trainer 03, Occupational Therapists (OTs), Female/ sighted person.).

For the purpose of this experiment Purposive sampling is used which is often accomplished as proposed by Etikan, Musa, \& Alkassim [17] by applying expert knowledge of the population to select in a nonrandom manner a sample of elements that represents a cross-section of the population. the researcher decides what needs to be known and sets out to find people who can and are willing to provide the information by virtue of knowledge or experience, using purposive sampling Nine Visually Impaired students were selected from different Visually Impairment cases and different ages, as per to the following criteria of selecting students to be part in BASAER team:

1- Equal number of totally Blind students and low vision students to provide the initial pairs for the experimental steps and also to study the results on both kinds of Visually Impairment. 2- Students need to be in the age range of 9-16. 3- Student must have average to excellent school achievement level. 4- Students must have an interest in science and math subjects. 5- Students need to have good orientation and mobility (O\&M) skills. 6- Students need to have good Occupational skills.7- students need to have a Recommendation from His math or science teachers. Based on these main criteria a group of students were chosen and then interviewed by BASAER team trainers, after that 9 students were chosen as the first group of members for BASAER team. As follows: 1- Majed (Male, totally blind, 15y).2- Ahmad (Male, totally blind, 15y). 3Feryal (Female, totally blind, 12y). 4- Hamza (male, totally blind, 14y). 5- Abed Allah (Male, totally blind, 13y). 6- Mamon (Male, Low vision, 13y). 7- Mohammad H (Male, Low vision, 14y).8- Mohammad S (Male, Low vision, 14y). 9- Ammar (Male, Low vision, 14y).

\subsection{Research questions}

The question was developed to meet the objective of the study.

RQ: are visually impaired students capable of building and programming educational robots if provided with adapted materials and instruction from well-trained educators in the fields of inclusive STEM Classrooms?

The research started with the Hypothesis that visually impaired students can build educational robots and program them if they receive adapted materials and guidance 
with guided instruction from well-trained educators in the fields of inclusive STEM Classrooms.

\subsection{Experiment}

First step. The first step was to research the literature for the aim of studying and analyzing similar projects which helped to provide an insight into available resources and tools for Accessibility, building educational robots and programing them, also the literature review enabled BASAER team to understand how to benefit from Opportunities and strengths and avoid weaknesses and threats.

Table 1. Literature Review for similar projects.team students.

\begin{tabular}{|c|c|c|c|c|}
\hline Year & Authors & Robot type & Programing platform & Results \\
\hline 2016 & $\begin{array}{l}\text { Lindsay, \& } \\
\text { others [16]. }\end{array}$ & $\begin{array}{l}\text { Lego Mind- } \\
\text { storm NXT }\end{array}$ & $\begin{array}{l}\text { NXT-G is a graphical com- } \\
\text { puter programming lan- } \\
\text { guage specifically designed } \\
\text { to program the LEGO NXT } \\
\text { robotics kit. }\end{array}$ & $\begin{array}{l}\text { The results show that modifications } \\
\text { which addressed the educational/curric- } \\
\text { ulum needs. Resulted in students en- } \\
\text { joyed the program and learning about } \\
\text { computer programming and building ro- } \\
\text { bots. }\end{array}$ \\
\hline 2019 & $\begin{array}{l}\text { Oliveira, \& } \\
\text { others [18]. }\end{array}$ & $\begin{array}{l}\text { 2D virtual ro- } \\
\text { bot }\end{array}$ & $\begin{array}{l}\text { GoDonnie programming } \\
\text { language }\end{array}$ & $\begin{array}{l}\text { The results indicate that GoDonnie has } \\
\text { good usability, and supports the devel- } \\
\text { opment of O\&M in VI and meets the } \\
\text { expectations regarding the programming } \\
\text { environment. }\end{array}$ \\
\hline 2010 & \begin{tabular}{|l|} 
Ludi \& oth- \\
ers [14]
\end{tabular} & $\begin{array}{l}\text { Lego Mind- } \\
\text { storm NXT }\end{array}$ & $\begin{array}{l}\text { JBrick (code programing } \\
\text { language) }\end{array}$ & $\begin{array}{l}\text { Results shows that JBrick can help VI } \\
\text { student to program robots }\end{array}$ \\
\hline 2015 & $\begin{array}{l}\text { Conchiha \& } \\
\text { others }[19]\end{array}$ & $\begin{array}{l}\text { Lego Mind- } \\
\text { storm NXT }\end{array}$ & $\begin{array}{l}\text { NXT-G is a graphical com- } \\
\text { puter programming }\end{array}$ & $\begin{array}{l}\text { The results shows that ER promotes stu- } \\
\text { dent inclusion in different and engaging } \\
\text { activities. }\end{array}$ \\
\hline 2018 & $\begin{array}{l}\text { Rumelt, S. } \\
{[20]}\end{array}$ & $\begin{array}{l}\text { Lego Mind- } \\
\text { storm NXT }\end{array}$ & NXT-G + JBrick & $\begin{array}{l}\text { The findings demonstrate confirmation } \\
\text { of the effectiveness of combining both } \\
\text { graphical programming language and } \\
\text { Code (text) programming languages }\end{array}$ \\
\hline 2020 & $\begin{array}{l}\text { Gonçalves, } \\
\& \text { others } \\
{[21]}\end{array}$ & $\begin{array}{l}\text { 2D virtual ro- } \\
\text { bot }\end{array}$ & $\begin{array}{l}\text { GoDonnie a programming } \\
\text { language }\end{array}$ & $\begin{array}{l}\text { GoDonnie have good usability support } \\
\text { for development of visually impaired } \\
\text { people, and it meet the requirements } \\
\text { concerning the programming environ- } \\
\text { ment but not the robot building part. }\end{array}$ \\
\hline 2017 & $\begin{array}{l}\text { Barros, } \\
\text { \&others } \\
{[22]}\end{array}$ & CardBot 2.0. & Mobile app & $\begin{array}{l}\text { The results show that validation of this } \\
\text { approach by performing experimental } \\
\text { classes for students with different visual } \\
\text { impairments and ages, showed a posi- } \\
\text { tive effect. }\end{array}$ \\
\hline
\end{tabular}

Step one has resulted in giving BASAER team a better understanding of the opportunities and challenges that face educational robotics for Visually Impaired, and also it demonstrated that the most used physical robots are LEGO Mindstorm NXT due to their ease of use for the pupils to recognize and locate the distinct robot parts and to finish building their robot designs, also it showed that modifications which addressed the curriculum needs, that included cognitive ,learning, physical needs, and social needs 
resulted in students enjoying programming and building robots in STEAM programs. the programming side of this experiment will be discussed in step five.

Second step. In this step BASAER team explored educational Robotics technologies available in marketplace that can be utilized to train Visually Impaired students or which can be adjusted for this intent, this was in the light of the results from the first step shown in Table 1. To understand how robot kits could help develop skills in building and design for blind students, chosen BASAER students whose ages ranged from 12 to 15 were exposed to real-world situations using various robotic platforms and kits with the main focus on Lego robot kits and also other available kits in the market. At this stage BASAER team goal was to evaluate which robot building kits were better suited for engaging Visually Impaired students. Using a team of Specialist mentors in the domains of visually impairment, Occupational therapy, Robotics, STEM, and science from the Blind academy school and the Jubilee center, Bright engineers center and the team trainers, each student was teamed with a sighted friend or low vision student who assisted the blind student by reading directions, handing the robot parts, and assisting with assembling the various parts of the system.

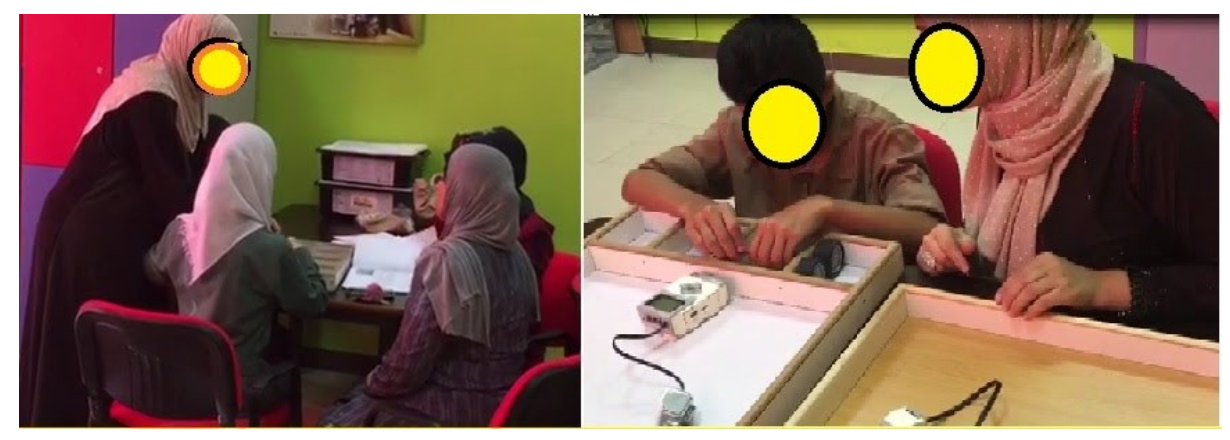

Fig. 1. Pictures of BASAER Robot-Building Activities

Various robotic platforms were tested including Arduino Robot Car Kit, Makeblock Mbot, Makeblock robot build kit, LEGO Mindstorm NXT, LEGO Mindstorm RCX, LEGO Mindstorm EV3 and Lego Education Wedo. Students were able to complete successfully constructing all of the various robot kits with the help of the sighted team, although with great difficulty. Several of the students who were using the Arduino and Makeblock kits complained that the parts were too small and challenging to handle. 


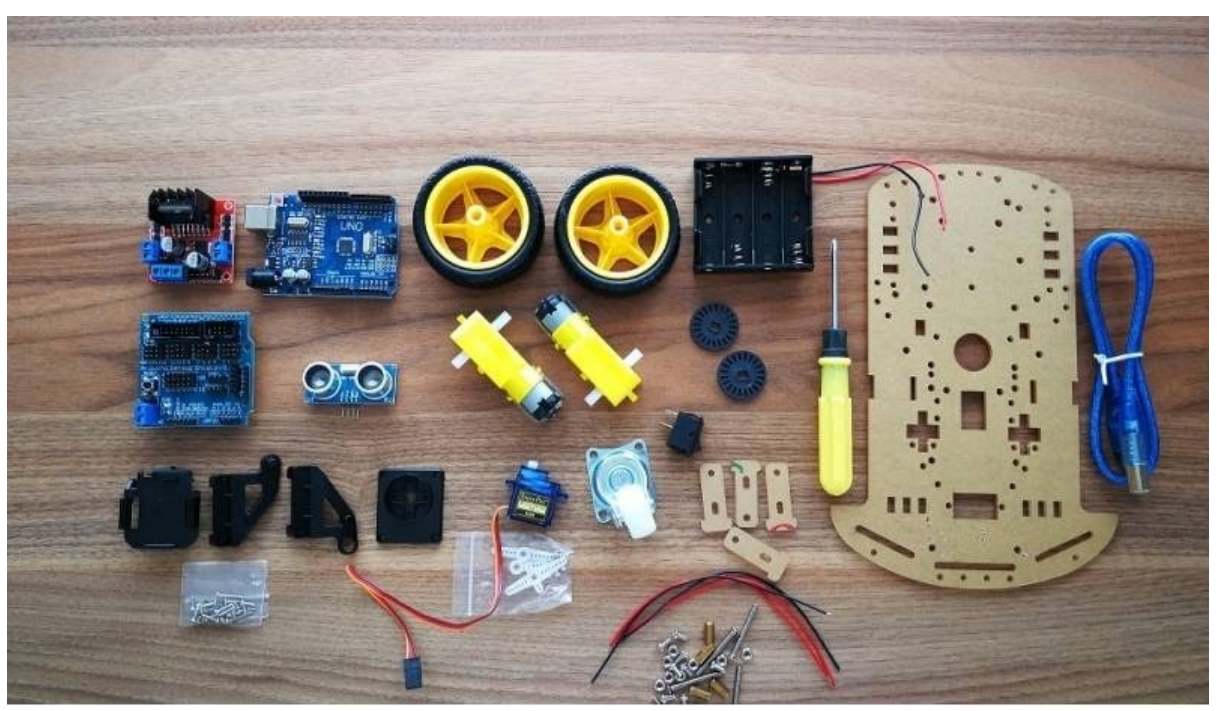

Fig. 2. Pictures of Arduino Robot Car Kit.

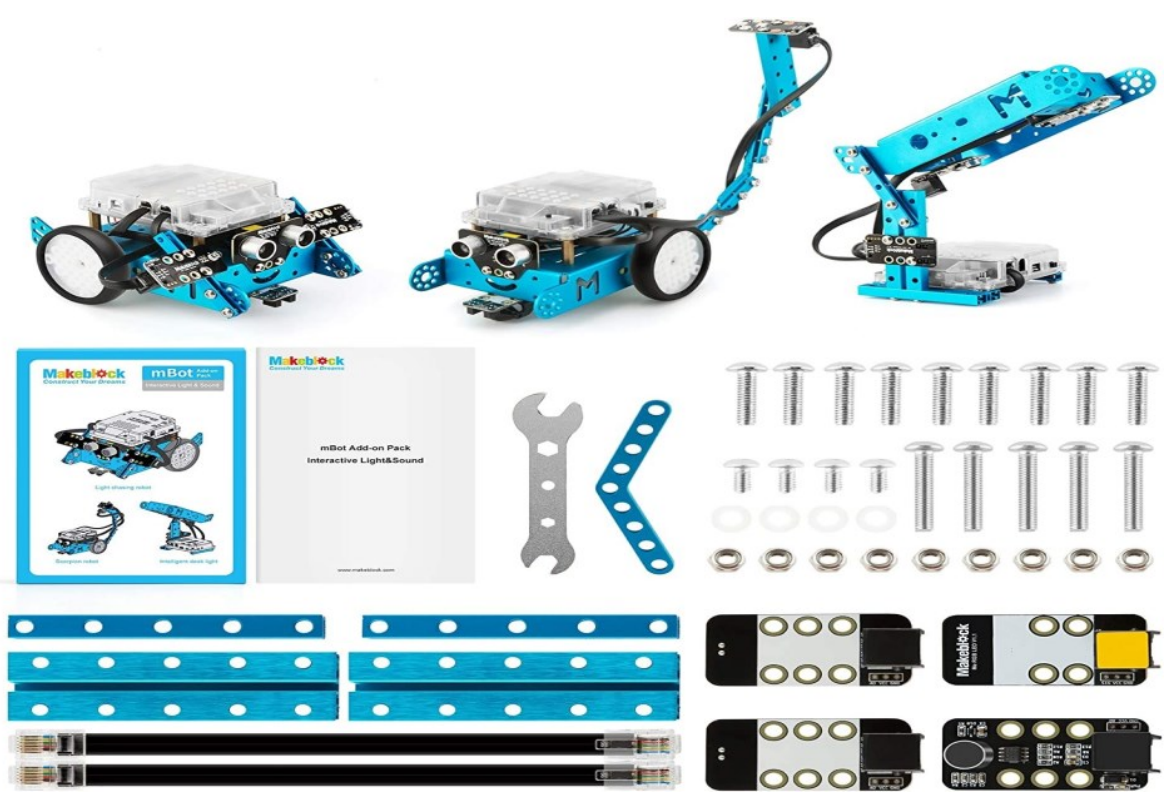

Fig. 3. Pictures of Makeblock Mbot Robot Kit.

Student teams also designed, built, and programmed robotic structures using LEGO Mindstorm NXT, LEGO Mindstorm RCX, LEGO Mindstorm EV3 and Lego Education Wedo Robotic Platforms. BASAER team reported that the students using the LEGO kits needed less intervention from their sighted buddies and that they found the LEGO 
parts easier to handle, identify, and place in their proper location to complete their robot. And the following table compares the different kits.

Table 2. Robot Kits comparison.

\begin{tabular}{|l|l|l|l|l|}
\hline Robot Kit name & $\begin{array}{l}\text { Availa- } \\
\text { bility }\end{array}$ & \multicolumn{1}{|c|}{ Price } & $\begin{array}{c}\text { Ease of use as per to VI } \\
\text { students }\end{array}$ & $\begin{array}{l}\text { Needs support from a sighted } \\
\text { person to assemble }\end{array}$ \\
\hline $\begin{array}{l}\text { Arduino Robot } \\
\text { Car Kit }\end{array}$ & Available & Around $20 \$$ & $\begin{array}{l}\text { Hard to manage the small } \\
\text { parts }\end{array}$ & $\begin{array}{l}\text { Support by sighted person is } \\
\text { required. }\end{array}$ \\
\hline Makeblock Mbot & Available & Around 70 \$ & Difficult to assemble. & $\begin{array}{l}\text { Support by sighted person is } \\
\text { required. }\end{array}$ \\
\hline $\begin{array}{l}\text { Makeblock robot } \\
\text { build kit }\end{array}$ & Available & Around 300 \$ & Difficult to assemble. & $\begin{array}{l}\text { Support by sighted person is } \\
\text { required. }\end{array}$ \\
\hline $\begin{array}{l}\text { LEGO Mind- } \\
\text { storm NXT }\end{array}$ & $\begin{array}{l}\text { Not } \\
\text { Available }\end{array}$ & Not Available & $\begin{array}{l}\text { Easy to assemble and man- } \\
\text { age the robot parts }\end{array}$ & $\begin{array}{l}\text { Support by sighted person is } \\
\text { required. }\end{array}$ \\
\hline $\begin{array}{l}\text { LEGO Mind- } \\
\text { storm RCX }\end{array}$ & $\begin{array}{l}\text { Not } \\
\text { Available }\end{array}$ & Not Available & $\begin{array}{l}\text { Easy to assemble and man- } \\
\text { age the robot parts }\end{array}$ & $\begin{array}{l}\text { Support by sighted person is } \\
\text { not required with the condition } \\
\text { of providing adaptation. }\end{array}$ \\
\hline $\begin{array}{l}\text { LEGO Mind- } \\
\text { storm EV3 }\end{array}$ & Available & Around 500 \$ & $\begin{array}{l}\text { Easy to assemble and man- } \\
\text { age the robot parts }\end{array}$ & $\begin{array}{l}\text { Support by sighted person is } \\
\text { not required with the condition } \\
\text { of providing adaptation. }\end{array}$ \\
\hline $\begin{array}{l}\text { Lego Education } \\
\text { Wedo kit }\end{array}$ & Available & Around 300 \$ & $\begin{array}{l}\text { Easy to assemble and man- } \\
\text { age the robot parts }\end{array}$ & $\begin{array}{l}\text { Support by sighted person is } \\
\text { not required with the condition } \\
\text { of providing adaptation. }\end{array}$ \\
\hline
\end{tabular}

Students found the LEGO Mindstorm EV3 to be the most user-friendly out of the four LEGO Robotic kits they used. The LEGO Mindstorm EV3 building components are made of simple parts with the conjunction of odd structures, made it simpler for the students to recognize the pieces and complete robot design (Figure 5). Based on BASAER team observation through these student interactions, it was concluded that the LEGO Mindstorm platforms were the most suitable for designing interactive robotbuilding tasks for blind and visually impaired students. And LEGO Mindstorm EV3 was chosen because it was the most recent Robot Kit from LEGO at that time plus it was available more than older versions like RCX.

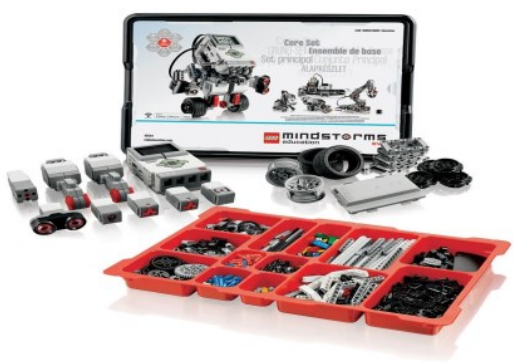

Fig. 4. LEGO Education EV3 Core Set

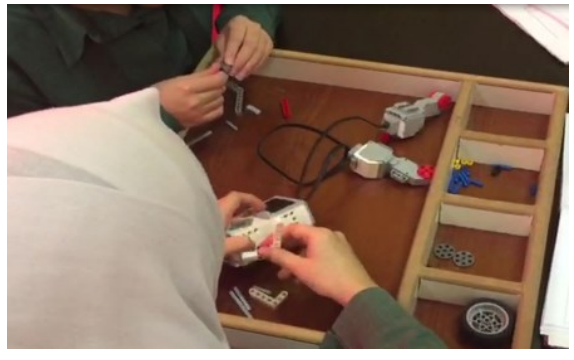

Fig. 5. BASAER team students building LEGO EV3 robot. 
Third step. The third step was to provide the needed specialized training for the program educators, and for this cause specialized training was presented by Jubilee school and Bright Engineers institute in the fields of building and programming Lego Mindstorm educational robots. Also, BASAER team trainers received training in Arduino tools and projects and Arduino language from Sofyan Al Taraouna center, and also training on Makeblock robot kits was provided from Belal AlFoury institute.

Fourth step. The fourth step was to create a modified hands-on curriculum for Teaching Visually Impaired Students robot-building activities that engage them in the engineering design necessary to accomplish the given objectives. So After the step of building LEGO EV3 robots by teams of blind-sighted students, BASAER team found that the guides and manuals provided from LEGO can create some confusion for blind students and also contains many steps in which they use many parts, which will always create the need for sighted person support for both reading the steps and helping in building and assembly, for these reasons BASAER team decided to create and provide a focused Robot curriculum for blind and the Visual Impaired students that was centered on Accessibility and building capacities through a braille guide for building modified robots, which featured simple LEGO robots with symmetric shape and middle center of Weight, the Guide also has a modified section for Robot parts which provided students with easy naming and identifying system for robot parts that was created and tested with blind students and teachers and also a description for designing a simple building box or container that BASAER team found it to be very important for blind students to manage robot parts and pieces and keep them from being out of reach of blind students or being lost.
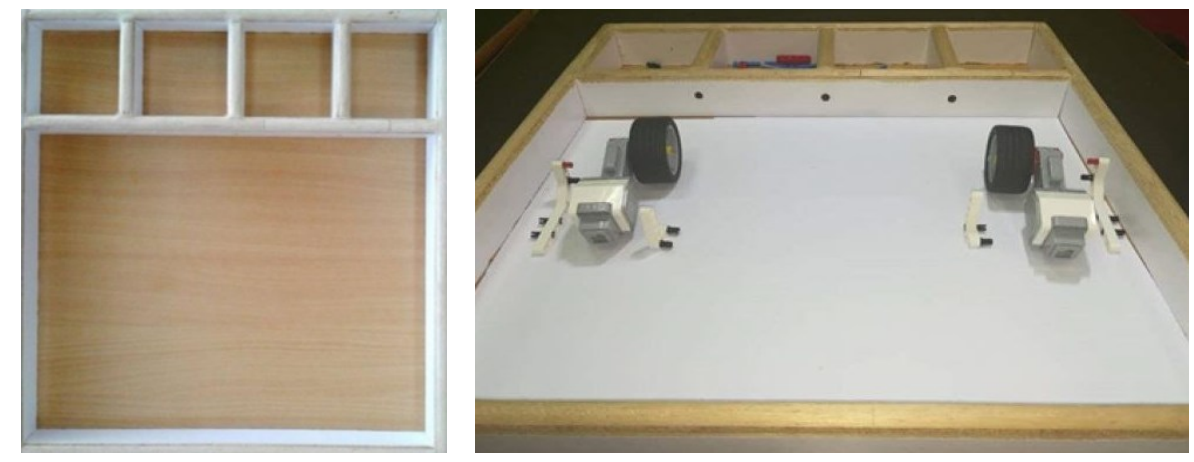

Fig. 6. BASAER team Building Box for robots. 


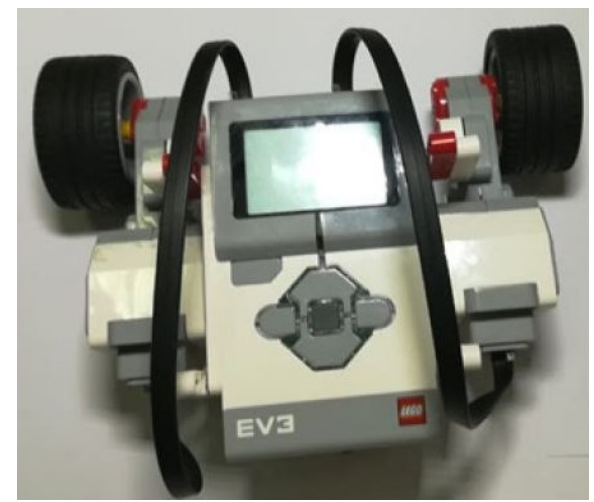

Fig. 7. BASAER team modified Robot.

The new BASAER guide helped blind and Visually Impaired students to build EV3 robot by themselves without the need for support or guidance from their teachers or sighted guides, just a small introduction on how to use the guide will be enough. Once students completed the first robots they were encouraged to build and add attachments that would give each robot a new advantage. A typical build session ranged from 30 minutes to 1 hour, depending on the complexity of the Robot desired and student ability and experience. The excitement of building the first robot had a direct computing influence in that students, where they began to express a desire to not only build the best robot but also to program their robot to perform different functions in order to give their Robot a competitive advantage. This naturally led to the next step in which BASAER team taught students how to program their robot using various accessible programming interfaces.

Fifth step. The fifth step was the investigation and augmentation of current educational programming programs and interfaces that will enable access to robot programming activities whichb are accessible for Visually Impaired students and that helps Developing the Capabilities of Blind and Visually Impaired Students to Program Robots. This was a strong requirement for these programs to be effective. Accessible interfaces consist of a collection of multi-modal interfaces that rely on the integration of text-tospeech translators, audio feedback, and haptic interfaces to engage students with visual impairments in robot-educational activities.

Among the significant technological advancements implemented in the present step is that the use of accessible interfaces to allow blind and visually impaired students to program robots. Although there were a number of available programming interfaces available for the LEGO Mindstorms which was using a graphical programing environment, it was not readable by the screen readers used by blind and visually impaired students, BASAER selected the ROBOTC programming language [4] for blind students or students with severely sight impairment as their programming interface due to its accessibility attributes. BASAER team then integrated the JAWS screen reader because it can read ROBOTC programing interface and help blind students or students with Severely sight impaired to write programming codes, and this was one of the many 
reasons to choose LEGO EV3 which is the ability to program this Robot with both written code and graphical programing environment.

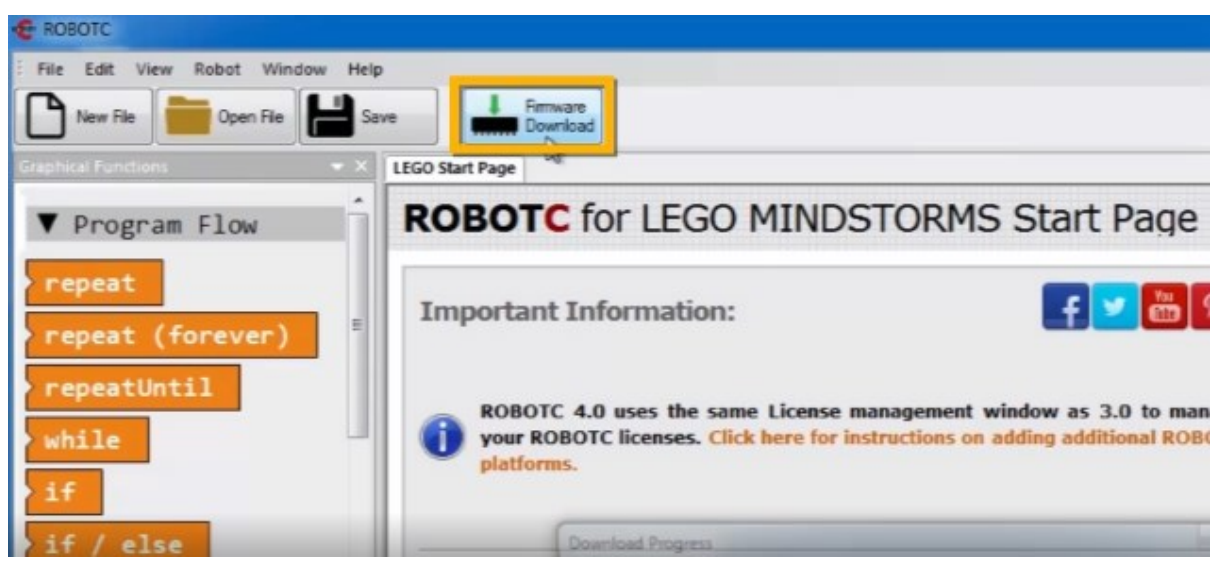

Fig. 8. ROBOTC programming platform

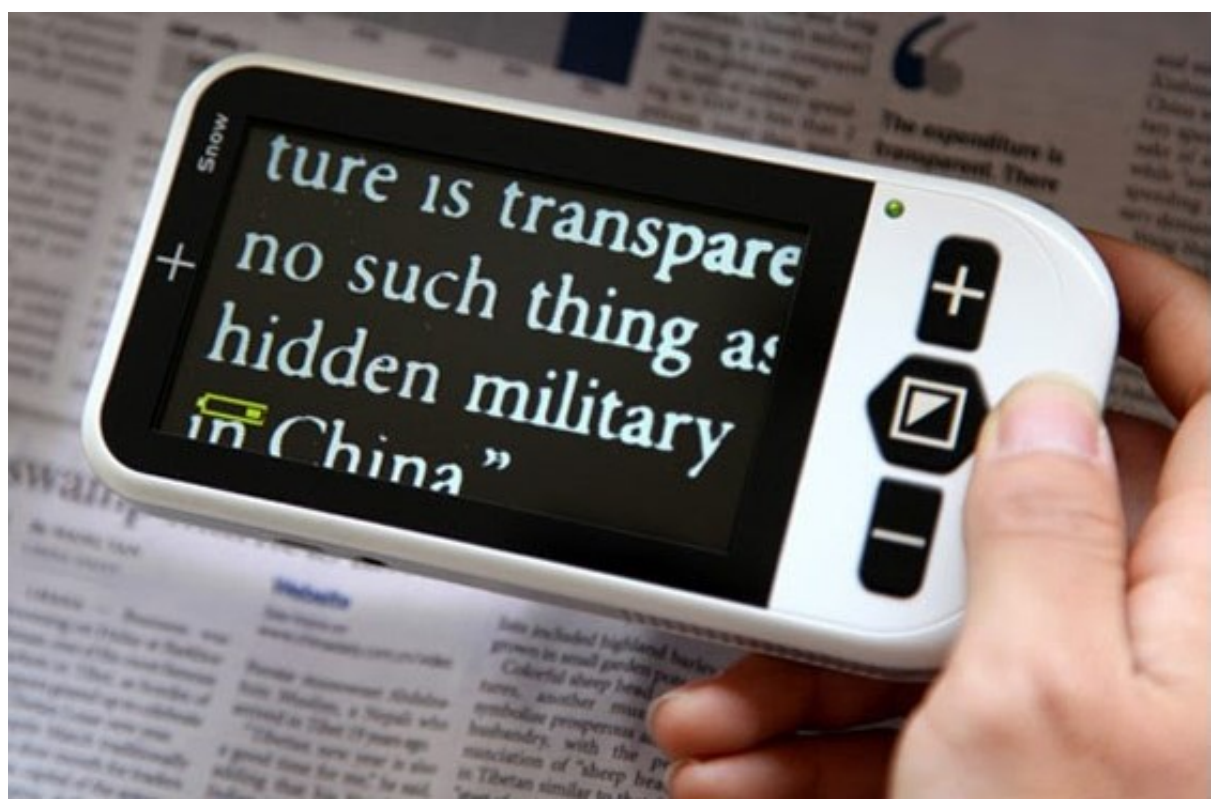

Fig. 9. Portable Electronic Magnifiers.

For low vision members of BASAER team MAGIC screen magnification software and visual magnifier was used to provide access to the programming environment (EV3 graphical programing environment), As the screen reader provides direct text to voice conversion for those designated as legally blind (i.e., having a visual acuity of 20/200 or less), and the magnifier provides text expansion. Using these different platforms, a 
training guide for programming was developed by BASAER team that utilized both ROBOTC programing interface and EV3 graphical programing environment, screen readers where implemented with EV3 graphical programing environment to display information for students, also a lesson plan that provided step by step instruction on the basic programming environment and syntax, such as compiling and downloading robot instructions, introduction of the robot command library, calling a function from the provided library, and figuring out how to call functions with input parameters. This self-explanatory teaching protocol was used to teach the basics for programming the robot.

To provide a focused objective for the robot programming activity, the students were given a task to program their robots to navigate through a set of tasks on a specific Mat which is installed on a training table which was used in FIRST® ${ }^{\circledR}$ LEGO ${ }^{\circledR}$ FLL[23] program competitions and collect points by completing certain tasks, the task was to first build the basic Robot using BASAER guide and then program the basic tasks using BASAER programming guide which provided students with a programmed robot that was capable of successfully navigating the Mat.

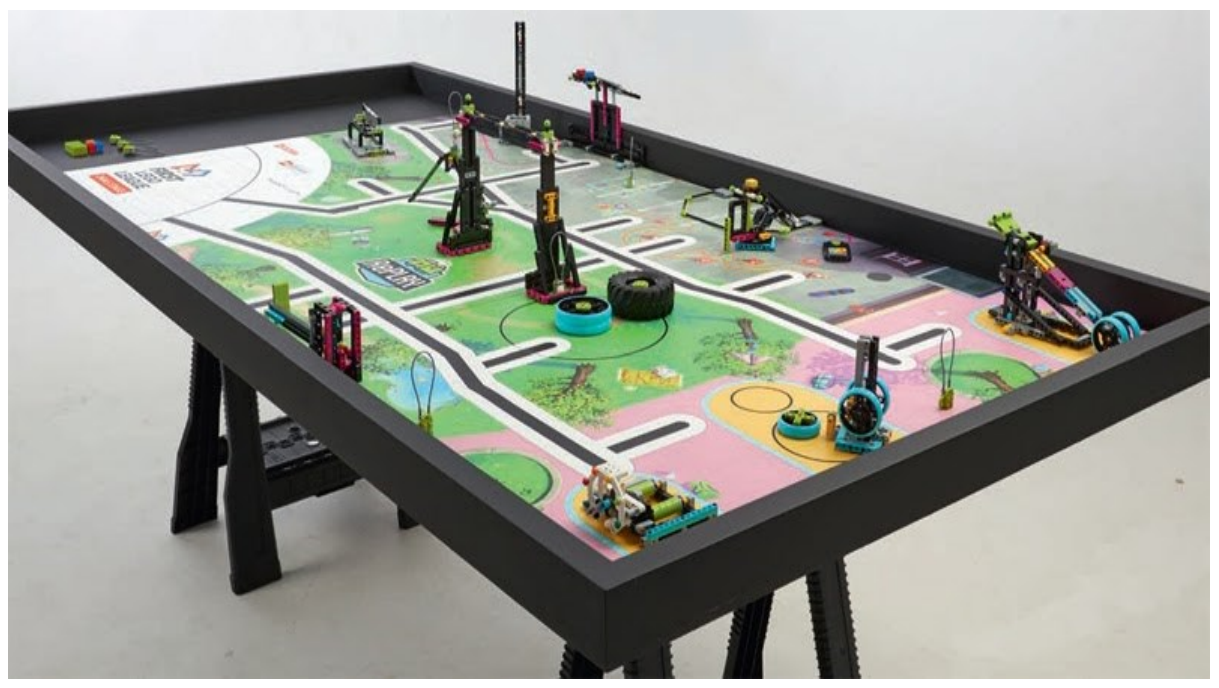

Fig. 10. FLL Mat and Table.

While the robot navigated through the Mat environment, the students were provided with haptic/audio feedback. During each run, each student would report what they felt their robot was doing This information was recorded and then provided to the students in order to enable them to update their robot design and programming to achieve more points from Mat tasks. Hence creating a competition factor which increased their engagement.

Sixth step. In this step, the planning, execution, evaluation, and refinement of BASAER project in conjunction with the Blind Academy for the Visually Impaired, the Ministry of education, and other institutions in Jordan. Planning, execution, evaluation and refinement were continuous processes that constantly changed based on the 
feedback from the different stakeholders and also new information gained from different sources. The instructional design process for BASAER team was executed in accordance with the ADDIE model. ADDIE stands for Analysis, Design, Development, Implementation, and Evaluation. This model relies on being able to analyze and evaluate feedback as part of the continuous improvement process [24]. The process is presented in a streamlined, focused manner, so that continual improvement can be attained.

In addition, all steps were tested and validated by blind students, teachers and Visual Impairment specialists, and the feedback was used to adapt both BASAER program and guides and also the implementation process. Despite BASAER team humble beginning, the team continued to be a huge success participating with many national and international robot competition and winning the first place prize for scientific research at the 2016 national FLL competition [25]. And many other prizes for BASAER junior team in FLL junior competition in 2016 and 2017, the team also participated in the 2016 INTEL ISEF (International Science and Engineering Fair) at Arizona, USA, as a finalist team and it was the first Blind team ever to participate in the International Fair. This great success of BASAER team was used as a model to create other special needs robotics teams in Jordan as an example Al Amal team for deaf students. And as a result of the continuous positive results, BASAER team and the Blind Academy School got a fund from USAID Jordan with the supervision of Al Hussain Foundation and the Ministry of education and Jubilee centre to create the First STEM room and curriculum for Visual Impaired students In the Middle East and the Region.

\section{Discussion and future work}

Through the research results, we can see that the BASAER Team project experiment has resulted in very interesting points, the results clearly shows that student with Vision Impairment are able to build and program educational robots if provided with the right environment, material and instruction adaptations with the supervision of motivated well-trained educators in the fields of inclusive STEM Classrooms.

The research found the LEGO Mindstorm EV3 robot kit very suitable for training students with Vision Impairment on building educational Robots, also the modified robot building guide created by BASAER team allowed totally blind and severely sight impaired students to build Robots independently without any support from sighted people. For programming the EV3 robots, this research found that low vision students can use the graphical computer programming in EV3 platform with the aid of magnifiers and the totally blind students can use RobotC programing language with the aid of JAWS screen reader. Research also found some limitations and challenges with the implementation of the process, totally blind and Severely sight impaired students were not able to run the programmed code or program if the EV3 robot was not connected to the laptop or computer, because EV3 robot brain have a graphical user interface, team members found a solution around that by keeping only one program saved and memorizing the steps to open and run the file without seeing the graphical user interface just by following audio clues . 
This research found that it is evident that visually impaired students can successfully build and program educational robots and also learn and participate in STEAM programs with success which can also lead them to pursue farther studies in STEAM majors and occupations. Future work focuses on the development and dissemination of training kits based on learned practices using the accessible robot building and programming interface tools. A strong benefit of this effort is the investigation and augmentation of alternative interfaces that can be shared with others such that educators can engage students with visual impairments in the classroom environment. It should be possible for teachers to use the training kits and the associated infrastructure to encourage students with visual impairments to participate in computer-related activities and STEAM education. Students themselves should be able to use the infrastructure to explore other programming activities independently. To support this effort, BASAER team are currently authoring a book with many additional resources and a website, YouTube channel and audio recordings that will allow easy access to documentation, learned practices, and modules. These resources will be self-contained and conform to accessible educational robotic activities.

\section{Conclusion}

The BASAER team project and its continuous success is an ongoing experiment where educators and specialists working in the fields of inclusion for Blind students in STEAM/STEM activities can learn a lot and use a ready created resources which were validated and tested with continuous success of this research. The research concludes that blind and Visually Impaired students can succeed and even excel in learning educational robots and STEAM with the conditions of providing them firstly with educators who are motivated and educated in the fields of inclusive educational technology in STEAM and secondly providing them with inclusive educational technology.

\section{Declaration of conflicting interests}

The authors declared no potential conflicts of interest with respect to the research, authorship, and/or publication of this article.

\section{$7 \quad$ References}

[1] R. Dorsey, C. Park, and A. Howard, "Developing the Capabilities of Blind and Visually Impaired Youth to Build and Program Robots," 2013. [Online]. Available: http://scholarworks.csun.edu/bitstream/handle/10211.3/121965/JTPD201406-p57-69.pdf? sequence $=1$

[2] A. Bilyalova, L. Bazarova, D. Salimova, and G. Patenko, "The Digital Educational Environment: The Problem of Its Accessibility for Visually Impaired Students," International Journal of Emerging Technologies in Learning (iJET), vol. 16, no. 16, p. 221, Aug. 2021, https://doi.org/10.3991/ijet.v16i16.23453 
Paper-BASAER Team: The First Arabic Robot Team for Building the Capacities of Visually Impaired...

[3] C. Karagiannidis, C. Kouroupetroglou, and A. Koumpis, "Special Needs at Different Educational Levels: A Forecast of 2020," International Journal of Emerging Technologies in Learning (iJET), vol. 7, no. 4, p. 4, Dec. 2012, https://doi.org/10.3991/ijet.v7i4.2168

[4] N. AbuSuliman and M. Hamash, A practical guide to teaching robotics to the blind, 01 ed. Kotobna, 2021.

[5] M. E. Cupples, P. M. Hart, A. Johnston, and A. J. Jackson, "Improving healthcare access for people with visual impairment and blindness," BMJ, vol. 344, no. jan30 1, pp. e542-e542, Jan. 2012, https://doi.org/10.1136/bmj.e542

[6] J. M. Angel-Fernandez and M. Vincze, "Towards a Definition of Educational Robotics," 2018. https://doi.org/10.15203/3187-22-1-08

[7] S. Riley, "What is STEAM education? A comprehensive guide for K-12 schools," The Institute for Arts Integration and STEAM, 2020. https://artsintegration.com/what-is-steam-education-in-k-12-schools/

[8] "STEAM Education in K-12 Schools: A Review of Evidence Required the IAS Definition of STEAM," The Institute for Arts Integration and STEAM, 2020. Accessed: Mar. 17, 2021. [Online]. Available: https://artsintegration.com/wp-content/uploads/2020/03/STEAMResearch-2020.pdf

[9] J. Kummanee, P. Nilsook, and P. Wannapiroon, "Digital Learning Ecosystem Involving STEAM Gamification for a Vocational Innovator," International Journal of Information and Education Technology, vol. 10, no. 7, pp. 533-539, 2020, https://doi.org/10.18178/ijiet. 2020.10.7.1420

[10] E. AlZireqat, Visual disability; Basic concepts and pedagogical considerations. massira, 2006.

[11] M. Sahin and N. Yorek, "Teaching science to visually impaired students: A small-scale qualitative study,” 2006. https://www.researchgate.net/publication/234621446 Teaching Science to Visually Impaired Students A Small-Scale Qualitative Study

[12] M. Sakalli Demirok, N. Gunduz, A. A. Yergazina, Z. A. Maydangalieva, and E. L. Ryazanova, "Determining the Opinions of Special Education Teachers Regarding the Use of Assistive Technologies for Overcoming Reading Difficulties," International Journal of Emerging Technologies in Learning (iJET), vol. 14, no. 22, p. 141, Nov. 2019, https://doi.org/ 10.3991/ijet.v14i22.11761

[13] A. Stefik, R. E. Ladner, W. Allee, and S. Mealin, "Computer Science Principles for Teachers of Blind and Visually Impaired Students," 2019. https://doi.org/10.1145/3287324.3287453

[14] S. Ludi, M. Abadi, Y. Fujiki, P. Sankaran, and S. Herzberg, "JBrick," Proceedings of the 12th international ACM SIGACCESS conference on Computers and accessibility - ASSETS '10, vol. 10, 2010, https://doi.org/10.1145/1878803.1878866

[15] A. M. Howard, C. H. Park, and S. Remy, "Using Haptic and Auditory Interaction Tools to Engage Students with Visual Impairments in Robot Programming Activities," IEEE Transactions on Learning Technologies, vol. 5, no. 1, pp. 87-95, 2012, https://doi.org/10.1109/ TLT.2011.28

[16] S. Lindsay and K. G. Hounsell, "Adapting a robotics program to enhance participation and interest in STEM among children with disabilities: a pilot study," Disability and Rehabilitation: Assistive Technology, vol. 12, no. 7, pp. 694-704, Oct. 2016, https://doi.org/10.1080/ $\underline{17483107.2016 .1229047}$

[17] I. Etikan, S. A. Musa, and R. S. Alkassim, "Comparison of Convenience Sampling and Purposive Sampling," American Journal of Theoretical and Applied Statistics, vol. 05, no. 01, Jan. 2016, https://doi.org/10.11648/j.ajtas.20160501.11

[18] J. D. Oliveira, M. de B. Campos, A. Amory, and R. H. Bordini, "GoDonnie: A Robot Programming Language to Improve Orientation and Mobility Skills in People Who are Visually 
Paper-BASAER Team: The First Arabic Robot Team for Building the Capacities of Visually Impaired...

Impaired," The 21st International ACM SIGACCESS Conference on Computers and Accessibility, vol. ASSETS '19, no. 3308561.3354599, Oct. 2019, https://doi.org/10. $\underline{1145 / 3308561}$

[19] C. Conchinha, P. Osorio, and J. C. de Freitas, "Playfulleaming: Educational Robotics applied to Students with Learning Disabilities," 2015 International Symposium on Computers in Education (SIIE), no. 978-15090-14354, 2015, https://doi.org/10.1109/SIIE. $\underline{2015.7451669}$

[20] S. Rumelt, Causes and Coping with Visual Impairment and Blindness. BoD - Books on Demand, 2018. https://doi.org/10.5772/66009

[21] D. Gonçalves, G. Santos, M. Campos, A. Amory, and I. Manssour, "Braille character detection using deep neural networks for an educational robot for visually impaired people," Anais do XVI Workshop de Visão Computacional (WVC 2020), Oct. 2020, https://doi. org/10.5753/wvc.2020.13492

[22] R. P. Barros, A. M. F. Burlamaqui, S. O. Azevedo, S. T. de L. Sá, L. M. G. Gonçalves, and A. A. R. S. da S Burlamaqui, "CardBot - Assistive Technology for Visually Impaired in Educational Robotics: Experiments and Results," IEEE Latin America Transactions, vol. 15, no. 3, pp. 517-527, 2017, https://doi.org/10.1109/TLA.2017.7867603

[23] "FIRST Lego League Challenge," Wikipedia, Apr. 15, 2021. https://en.wikipedia.org/wiki/FIRST_Lego_League_Challenge (accessed Apr. 28, 2021).

[24] E. Quigley, "ADDIE Model: 5 Steps To Build Effective Training Programs | LearnUpon," LearnUpon, Oct. 03, 2019. https://www.learnupon.com/blog/addie-5-steps/

[25] “Arab Robot Magazine -2nd edition.," arabrobotics.org, 2016. http://arabrobotics.org/DataFiles/Magazine/Second-Issue/mobile/index.html $\# \mathrm{p}=78$

\section{Authors}

Mahmoud Hamash is a Master degree student in Educational Technology at Universiti Teknologi Malaysia, Malaysia. He works as a Digital learning implementation specialist (DLIS) (email: trainer.mahmoudhammash@yahoo.com).

Hasnah Mohamed received a M. Ed. (Education Technology) degree in 2002 and Ph.D. degree in Educational Technology in 2012 from UTM, Malaysia. She is a Senior Lecturer in the School of Education, Faculty of Social Science and Humanities, Universiti Teknologi Malaysia (UTM) since 2013. Formerly, she had served as a secondary school teacher for 16 years. She has published and co-authored numerous technical papers mainly in the education area, has been the editors for several journals, book chapters and conference proceedings, besides serving as reviewers and technical committee members of journals in the related fields. Her research interests include computer-assisted learning, computer-assisted instruction, flipped classroom, gamification and other education related research (email: hasnah-m@utm.my).

Article submitted 2021-09-28. Resubmitted 2021-10-24. Final acceptance 2021-10-25. Final version published as submitted by the authors. 